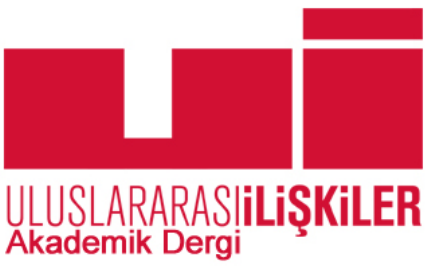

Yayın ilkeleri, izinler ve abonelik hakkında ayrıntılı bilgi:

E-mail: bilgi@uidergisi.com.tr

Web: www.uidergisi.com.tr

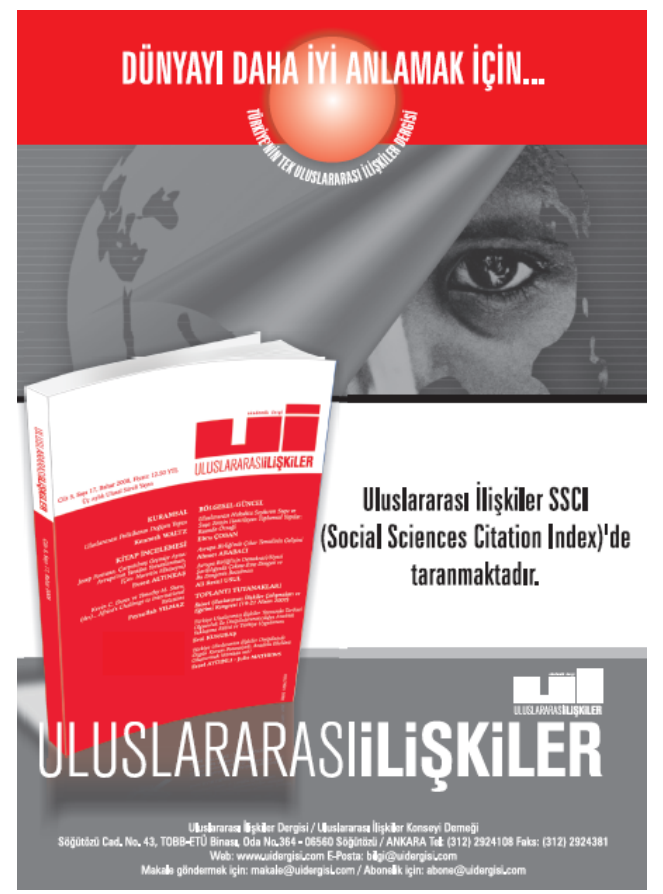

\title{
Pakistan Sivil-Askeri İlişkileri ve Belucistan Catışması
}

\author{
Murat ÜLGÜL* \\ * Dr., Uluslararası İlişkiler Bölümü, İ̈BF, Karadeniz Teknik \\ Üniversitesi
}

Bu makaleye atıf için: Ülgül, Murat, "Pakistan Sivil-Askeri İlişkileri ve Belücistan Çatışması", Uluslararası İlişkiler, Cilt 13, Say1 50, 2016, s. 59-75.

Bu makalenin tüm hakları Uluslararası İlişkiler Konseyi Derneği'ne aittir. Önceden yazılı izin alınmadan hiç bir iletişim, kopyalama ya da yayın sistemi kullanılarak yeniden yayımlanamaz, çoğaltılamaz, dağıtılamaz, satılamaz veya herhangi bir şekilde kamunun ücretli/ücretsiz kullanımına sunulamaz. Akademik ve haber amaçlı kısa alıntılar bu kuralın dışındadır.

Aksi belirtilmediği sürece Uluslararası Illişkiler'de yayınlanan yazılarda belirtilen fikirler yalnızca yazarına/yazarlarına aittir. UİK Derneğini, editörleri ve diğer yazarları bağlamaz. 


\title{
Pakistan Sivil-Askeri İlişkileri ve Belucistan Çatışması
}

\author{
Murat ÜLGÜL \\ Dr., Uluslararası İlişkiler Bölümü, İİF, Karadeniz Teknik Üniversitesi, Trabzon. \\ E-posta:mulgul@udel.edu,mulgul@ktu.edu.tr
}

\section{ÖZET}

Bu makalenin amacı Müşerref askeri rejimi ve Zerdari (Pakistan Halk Partisi) sivil rejimi dönemlerinde Pakistan'ın önemli bir iç sorunu olan Belucistan çatışması üzerinden sivillerle askerlerin etnik çatışmaların çözümüne yönelik yöntem farklılıklarını incelemektir. Bulgular Pakistan'da ordunun ve ordu-kökenli yöneticilerin homojen olarak Belucistan sorununu askeri önlemlerle çözme yanlısı olduğunu gösterirken, siyasi açıdan güçsüz olan sivil yöneticilerin çatışmaya daha geniş bir perspektifle baktığını ortaya koymaktadır. İki grup arasındaki yöntem farklılıkları kişisel ve kurumsal çıkarlar ile askeri düşünce yapısı sebebiyle askerlerin sivillere nazaran güç kullanmaya daha meyilli olduklarını öngören askeri aktivizm görüşü ile açıklanmaktadır.

Anahtar Kelimeler: Pakistan, Belucistan Sorunu, Askeri Aktivizm, Sivil-Asker İlişkileri, Etnik Çatışma

\section{Civil-Military Relations in Pakistan and the Baluchistan Conflict}

\begin{abstract}
This article analyzes the differences between civilians' and soldiers' approach to the solutions of ethnic conflicts through the Baluchistan conflict, an important domestic problem in Pakistan during the Musharraf military regime and Zardari civilian regime. The findings show that the military and military-origined politicians preferred to solve the Baluchistan conflict through military measures whereas politically-weak civilians looked at the conflict through a wider perspective. The methodological differences between these groups will be explained with the military activism perspective which argues that soldiers are more war-prone than civilians because of institutional and personal interests as well as military-mindset.
\end{abstract}

Keywords: Pakistan, Baluchistan Conflict, Military Activism, Civil-Military Relations, Ethnic Conflict 
Pakistan devleti 14 Ağustos 1947 tarihinde kurulmasından itibaren çalkantılı bir siyasi tarihe sahip olmuştur. Devlet yönetimi dönemsel olarak askeri ve sivil yönetimler arasında el değiştirmiş, ekonomik ve siyasi istikrar sağlanamamış, ülke komşularıyla (özellikle Hindistan ve Afganistan ile) sürekli bir çatışma içinde olmuş, son yıllarda radikal İslami gruplar ülkede konumlanmış ve nükleer silahlanmayla birlikte Pakistan küresel güvenlik açısından bir tehdit haline gelmiştir. Bütün bu sorunların yanında Pakistan çok-etnikli yapısıyla da bir çatışma merkezi olmuş, farklı etnik gruplar kurucu ideolojisi İslam olan devletin çatısı altında politik, ekonomik ve sosyal anlaşmazlıklarını çözmekte zorlanmışlardır. Özellikle Doğu Pakistan'da yaşayan Bengalliler ile merkezi hükümet arasında yaşanan anlaşmazlıklar 1947'den itibaren şiddetlenerek artmış ve 1970 seçimlerinin ardından Bengalliler, Hindistan'ın da yardımıyla, Bangladeş adıyla bağımsızlıklarını ilan etmiştir. Böylece Pakistan İkinci Dünya Savaşı sonrası bölünen ilk ülke olurken, bu durum etnik gruplar arasındaki ilişkilerde bir ilerleme yaratmamış, aksine ülkedeki Pencaplılar, Sindiler, Muhacirler, Peştunlar ve Beluciler sürekli bir çatışma içinde olmuştur.

Bu makale 2000’li yıllarda şiddetini artıran Belucistan çatışmasını örnek-olay çalışması kabul ederek Pakistan'da asker ve sivillerin etnik sorunlara bakış açısını ve bu sorunları çözme yaklaşımlarını analiz edecektir.

Bengallilere benzer şekilde, Beluciler 1947’de Pakistan bağımsızlı̆ını ilan ettiğinde gönülsüz olarak yeni kurulan devlete katılmış ve o günden bu güne farklı zamanlarda merkezi hükümete karşı isyan bayrağını açmışlardır. En son isyan 2005 yılında başlamış ve etnik çatışma durumu bazen şiddeti artarak bazen azalarak günümüze kadar sürmüştür. Bu çalışmanın analiz edeceği zaman dilimleri 20052008 Müşerref askeri rejimi ve 2009-2012 Zerdari (Pakistan Halk Partisi) sivil rejimi dönemleridir. Makalenin amacı söz konusu dönemlerde askerlerle siviller arasında etnik çatışmalara yönelik yöntem farklılıklarını incelemek ve sivil-asker ilişkilerinin etnik çatışmalara etkisinin olup olmadığını ortaya koymaktır. Makaledeki bulgular Pakistan'da askerlerin ve asker-kökenli yöneticilerin homojen olarak etnik sorunları güç kullanma yoluyla çözme çabası içinde olduklarını gösterirken, sivil yöneticilerin Belucistan sorununa daha geniş bir perspektiften baktıklarını ve diplomatik, ekonomik ve sosyal çözüm yollarına başvurma niyeti taşıdıklarını ortaya koymaktadır. Çalışma gerek Belucistan çatışması gibi Türkiye'de pek incelenmeyen bir olayı analiz ederek gerekse teorik açıdan birtakım boşlukları doldurarak literatüre katkıda bulunmayı hedeflemektedir.

İlerleyen sayfalarda öncelikle Pakistan'daki sivil-asker ilişkileri ve Belucistan çatışması hakkında kısa bir tarihsel bilgi verilecektir. Ardından Müşerref ve Zerdari dönemlerinde asker ve sivillerin Belucistan sorununa yaklaşımları analiz edilecektir. Makalede söz konusu dönemlerde siviller ile askerler arasındaki yaklaşım farklılıkları tespit edildikten sonra bu farklılıkların nereden kaynaklandığı sorusuna, uluslararası çatışma literatüründe yer alan "askeri aktivizm” perspektifinin yardımıyla cevap verilmeye çalışlacaktır. Çalışmanın sonuç bölümünde bulgular özetlenecek ve makalenin literatüre katkısı irdelenecektir.

\section{Pakistan Sivil-Askeri İlişkileri ve Belucistan Çatışmasının Kısa Tarihi}

Pakistan siyasi tarihi bir bakıma askeri darbeler ve yönetimler tarihi olsa da, 14 Ağustos 1947'de devlet ilk kurulduğunda siviller orduyu kontrol etmek adına uygun şartlara sahipti. İngiltere'nin Britanya Hindistanı ordusunu bölmesi genel anlamda Hindistan devleti lehine gerçekleştiğinden Pakistan ordusu personel, mühimmat ve askeri tesis anlamında yetersiz düzeyde kalmış, ${ }^{1}$ sivil

1 Hasan-Askari Rizvi, Military, State and Society in Pakistan, New York, St. Martin’s Press, 2000, s.60. 
yönetim de karizmatik hukukçu ve devlet adamı Muhammed Ali Cinnah'ın otoritesi altında toplanmıştı. İngiliz yönetimi altındaki eski Hindistan ordusunda verilen eğitim, askerlerin sivillerin otoritesine saygı duymasını ve politik görüşe sahip olmamasını öngörüyordu. ${ }^{2}$ Bu avantajlı duruma rağmen Cinnah'ın 1948'deki ölümünü takip eden politik istikrarsızlık ile Hindistan ve Afganistan'ın Pakistan ile yaşadıkları toprak anlaşmazlıkları orduyu kısa sürede maddi ve manevi açılardan güçlendirmiş ve General Eyüp Han'ın 1951'deki başkumandanlığı ile birlikte ordu Pakistan siyasal hayatındaki en önemli aktör haline gelmiştir. Askerler 1951-1958 yılları arasında bürokratik darbelerle sivil hükümetlerin devrilmesinde aktif rol oynamışlardır. Bu bürokratik darbelerin birinin ardından meydana gelen Eyüp Han sessiz darbesi 27 Ekim 1958'de Pakistan tarihindeki ilk askeri rejim dönemini başlatmıştır.

1958'den 1969'a kadar süren Eyüp Han rejimi, ordu destekli biçimde yönetimi merkezileştirme politikalarına öncelik vermiş ve etnik gruplar, özellikle de Doğu Pakistan'da yaşayan Bengalliler ağır bir baskı altında tutulmuşlardır. ${ }^{3}$ Eyüp Han rejiminin, 1965'deki İkinci Hindistan-Pakistan Savaşı sırasında, Doğu Pakistan'ın güvenliğini Keşmir uğruna tehlikeye atması nedeniyle rejime karşı artan protestolara rağmen Eyüp Han, yönetimi 1969'da siviller yerine Başkumandan Yahya Han’a devretmiştir. Yahya Han askeri rejimi, Aralık 1970'de yapılan seçimlerde Bengalli Awami Ligi'nin kazandığı başarı üzerine parlamentonun açılmasını ertelemiş ve Mart 1971'de Doğu Pakistan'a askeri operasyon düzenlemiştir. Çatışmalar Aralık 1971'de Hindistan'ın Pakistan’a müdahalesiyle sona ermiş ve Doğu Pakistan Bangladeş adıyla bağımsızlığını ilan etmiştir. ${ }^{4}$

Savaş Pakistan ordusunun itibar kaybına yol açmış ve askerler aradan geçen on üç yılın ardından gönülsüzce de olsa iktidarı Zülfikar Ali Butto yönetimindeki sivil hükümete devretmiştir. Butto orduyu sivil kurumları güçlendirmeden, kendi otoriter düzeninde kişisel kontrolü altına almaya çalışmıştır. ${ }^{5}$ Bu yaklaşımın yarattığı siyasi istikrarsızlık 1977 'de General Ziya ül-Hak yönetiminde yeni bir askeri darbeyi beraberinde getirmiştir. General Ziya 1988'de bir uçak kazasında ölünceye kadar politik amaçlarla İslam’ı da kullanarak yönetimsel mekanizmaları merkezileştirmeyi ve ordunun siyaset üzerindeki hâkimiyetini artırmayı amaçlamıştır. Onun döneminin eseri olan anayasanın meşhur 58(2)(b) maddesi cumhurbaşkanına başbakanı görevden alma ve parlamentoyu fes etme yetkisi vererek ordunun General Ziya öldükten sonraki dönemde de sivil siyaseti kontrol etmesine zemin hazırlamıştır. ${ }^{6}$ Gerçekten de her ne kadar 1988'de sivil yönetime geçilse de bir sonraki askeri darbeye kadar geçen on bir yılda Başbakan Benazir Butto iki kez, Navaz Şerif ise bir kez 58(2)(b) maddesi yoluyla ordu destekli bürokratik darbeye maruz kalmıştır. Şerif bu maddeyi ikinci başbakanlık döneminde yürürlükten kaldırsa da, bu durum 1999'da bürokratik darbe yerine General Pervez Müşerref önderliğinde doğrudan bir askeri darbenin yaşanmasıyla neticelenmiştir. ${ }^{7}$

2 Lloyd I. Rudolph ve Susanne Hoeber Rudolph, "Generals and Politicians in India”, Pacific Affairs, Cilt 37, No.1, 1964 , s.9.

3 Eyüp Han döneminin ayrıntılı bir incelemesi için bkz. Herbert Feldman, "Revolution in Pakistan: A Study of the Martial Law Administration" ve "From Crisis to Crisis: Pakistan 1962-1969”, The Herbert Feldman Omnibus, New York, Oxford University Press, 2001. eser omnibus olarak geçiyor, 3 kitabın tek ciltte toplanmıs hali, yani derleme bir kaynak değil, her alt-kitap sayfa 1'den başladığı için sayfa numaraları ile değil, eser isimleriyle vermeyi daha uygun gördüm.

4 Bu dönem için bkz. Richard Sisson ve Leo E. Rose, War and Secession: Pakistan, India and the Creation of Bangladesh, Berkeley, University of California Press, 1990.

5 Stephen Philip Cohen, The Idea of Pakistan, District of Columbia, Brookings Institution Press, 2004, s.78; Saeed Shafqat, Civil-Military Relations in Pakistan: From Zulfikar Ali Bhutto to Benazir Bhutto, Colorado, Westview Press, 1997, s.167.

6 Pakistan'da cumhurbaşkanları ya ordu kökenli ya da ordu destekli olarak göreve gelmişlerdir. Bu durumu Abdullah Gül öncesi dönem Türkiye'sindeki ordunun cumhurbaşkanı seçimlerine etki etmesine benzetebiliriz.

7 Celia W. Dugger, “Pakistani Premier Prevails in Clash with General”, New York Times, 20 Ekim 1998, http://www.nytimes. com/1998/10/20/world/pakistani-premier-prevails-in-clash-with-general.html (Erişim Tarihi: 29 Ocak 2015). 
Pakistan'ın bu çalkantılı politik geçmişinin temelden etki ettiği konuların başında ülkedeki etnik gruplar ile devlet arasındaki ilişkiler gelmektedir. Pakistan devlet olarak vücut bulduğunda kurucu ideoloji "iki halk teorisi" temelinde İslam olmuş ve etnik kimlikler arasındaki farklar göz ardı edilmiştir. Buna ilaveten 1951 nüfus sayımına göre nüfusun yüzde 29'unu oluşturan Pencaplılar ilk yıllardan itibaren bürokrasi ve orduda kontrolü eline almış, bu durum özellikle nüfusun yüzde 56'sını oluşturan Bengallilerin tepkisini çekmiştir. Bengalliler, bağımsızlığın ilanından itibaren kültürel, ekonomik ve politik açılardan ayrımcılığa maruz kalmış, ama en azından 1947'den 1958'e kadar olan sivil dönemde siyasi katılım yoluyla sorunlarını politik arenada dile getirebilmişlerdir. Askeri rejim döneminde gerek merkezileşme politikaları gerekse askeri yöneticilerin Bengallileri Hindistan tehdidinin bir parçası olarak görmeleri nedeniyle bu unsurların ülkeye yabancılaşmaları artmıştır. Bu yabancılaşma, 1970 seçimlerinin ardından çatışmaya dönüşmüş ve sonuçta Bengallilerin bağımsızlıklarını elde etmeleri nedeniyle Pakistan'ı İkinci Dünya Savaşı sonrası dönemde bölünen ilk ülke yapmıştır.

Bu dönemde Bengallilerle merkezi hükümet arasında yaşanan sorunların bir benzeri daha küçük ölçekte Batı Pakistan'da Belucilerle devlet arasında yaşanmıştır. Beluciler en başından Pakistan devleti fikrini benimsememiş, Pakistan’ın bağımsızlığının ilanından bir gün sonra Kalat Hanı Ahmet Yar Han önderliğinde Batı Pakistan’ın yüzölçümünün neredeyse yarısını oluşturan Belucistan eyaletinde bağımsız devlet ilan etmişlerdi. Fakat toplam nüfusun sadece yüzde 1,5'unu oluşturan Beluciler Pakistan ordusuna direnemeyince, Ahmet Yar Han Nisan 1948'de Pakistan'a katılım anlaşmasını imzalamak zorunda kalmıştır. Bu gönülsüz katılım Beluciler ile merkezi hükümet arasındaki sorunları çözmemiş, aksine Bengallilerle hemen hemen aynı sorunları (etnik dilin Urdu lehine dışlanması, merkez ile eyalet arasındaki ekonomik dengesizlik, bürokrasi ve orduda düşük temsil vb.) yaşayan Beluciler Pakistan devletiyle bütünleşememiştir.

İkinci Beluci ayaklanması 6 Ekim 1958'de Kalat Hanı’nın 80,000 kişilik bir güçle devlete isyan edeceği gerekçesiyle tutuklanmasıyla başlamıştır. Bunun üzerine Navab Nevruz Han liderliğindeki Beluciler gerilla savaşı başlatmış, silah bırakmak için Han’ın serbest bırakılmasını ve Batı Pakistan eyaletlerini birleştiren yönetim sisteminin ilgasını talep etmişlerdir. Askeri rejim bu taleplere cevaben bölgedeki askeri varlığını artırmış, Beluci köylerini bombalamış ve çok sayıda rejim muhalifini tutuklamıştır. Her ne kadar Nevruz Han ve adamları 1960'da tutuklansa da çatışmalar Yahya Han dönemine kadar sürmüştür. İsyan 1964'de hapiste ölen Nevruz Han gibi ulusal kahramanlar ve "Belucistan kasabı" olarak da anılan Pakistan ordusunu komutanı General Tikka Han gibi ulusal düşmanlar yaratarak bölgede Belucistan milliyetçiliğini beslemiştir.

Belucilerin durumunda Butto döneminin ilk yıllarında geçmişe kıyasla bir ilerleme olmuştur. Merkezi hükümet Mart 1972'de, 1970 seçimlerinden Belucistan bölgesinde galip çıan Ulusal Avami Partisi ve İslam Cemiyeti (UAP-İC) ile sıkıyönetimin kaldırılması, geçici anayasanın hazırlanması ve UAP-İC liderliğinde bölgesel bir hükümetin kurulması konusunda anlaşmıştır. Fakat bu anlaşma kısa süreli sonuçlar doğurmuş, Butto hükümeti ile yerel liderler arasındaki güç mücadelesi, 19731977 yılları arasında önceki isyanlardan daha büyük üçüncü bir Belucistan ayaklanmasının çıkmasına neden olmuştur. Butto ve onu destekleyen yerel liderler orduyu bölgede serbest bırakmış ve İran helikopterleri ${ }^{9}$ ile desteklenen 80,000 kişilik Pakistan ordusu 55,000 kişilik Beluci isyancıları

8 Bu teori Britanya Hindistanı́nda Müslümanlarla Hinduların iki farklı halk olduğuna vurgu yaparak Müslümanların ayrı bir devlete sahip olma hakları olduğunu savunmaktadır.

9 Beluciler Britanya Hindistanı zamanında oluşan toprak dağılımı neticesinde bugün Pakistan, İran ve Afganistan topraklarında yaşamaktadır. Ortak Beluci sorunu bu ülkeler arasında bazen gerilime neden olurken, bazen de diğer ülkelerdeki çatışmaların kendi topraklarına sıçrayabileceği endişesiyle işbirliğini de getirebilmektedir. 
kolaylıkla bastırmıştır. General Ziya döneminde isyancılara af çıksa da askeri rejim yerel Beluci hükümetini yeniden tesis etmemiş ve bölgede politik tutuklamalara devam etmiştir. ${ }^{10} 1988$-1999 sivil hükümetler döneminde ise her ne kadar merkezi hükümet Belucilerin sorunlarına ilgisiz kalsa da yerel liderler ulusal partilerden aday olarak bölgenin meselelerini Pakistan'ın siyasal gündeminde tutmayı başarmışlardır. Bölgede Müşerref dönemine kadar büyük çaplı bir isyan görülmemiştir.

\section{Müşerref Döneminde (2005-2008) Belucistan Çatışması}

Müşerref dönemine gelindiğinde isyanlar geçmişte kaldı gibi görünse de Belucilerin ekonomik, sosyal ve politik sorunları yeni bir isyanın yaşanması için sadece bir kıvılcım gerektiriyordu. Belucistan 2000'lerde, doğalgaz, kömür, uranyum, platin, altın ve petrol gibi zengin kaynaklara sahip olmakla birlikte Pakistan'ın en fakir eyaleti konumundaydı. 2006 yılında Belucistan'da halkın yüzde 20'si temiz içme suyuna ulaşabiliyorken, elektrik eyaletin sadece yüzde 25 'ine verilmekteydi. Topraklarının yüzde 94'ü işlenemez durumda olan eyalette nüfusun büyük kısmı işsiz olup okuma yazma bilmiyordu. Pakistan'da ilk doğalgaz 1952'de Belucistan'ın Sui bölgesinde keşfedilmiş olsa da doğalgaz eyaletin başkenti Ketta'ya ancak 1976'da, bölgedeki isyanı bastırmak için konumlanan ordunun ihtiyacını karşılamak amacıyla ulaşmıştı. ${ }^{11}$ Bölge halkının bir kısmı 2000’li yıllarda dahi ısınma ihtiyacını hala ardıç ormanlarından temin edilen odunlarla karşılıyordu. ${ }^{12} \mathrm{Bu}$ ve benzeri diğer faktörler Belucistan halkının arasında aynı 1971 öncesi Bengallilerin hissettiği gibi, bir eşitsizlik ve yerel etnik unsurlar aleyhine merkezileşme algısı yaratmıştır.

Müşerref rejiminin 2002 yılında Belucistan’ın kıyı kenti olan Gvadar'da başlattığı açık deniz limanı projesi bu algı̀ı daha da güçlendirmiştir. General Müşerref Gvadar projesi ile hem Orta Asya, Orta Doğu ve Uzak Doğu arasında bir enerji bağlantı noktası kurmak istemiş hem de askeri açıdan olası bir Hindistan ablukasına açık olan deniz kuvvetlerinin Karaçi'deki karargâhına güvenilir bir alternatif yaratmak istemiştir. ${ }^{13}$ Fakat projenin merkezden yönetilmesi, yerel politikacıların ve kurumların karar mekanizmalarında olmayışı, iş imkânlarının ve Gvadar çevresindeki arazilerin Beluci olmayan sivil ve askeri personele verilmesi gibi unsurların yanı sıra bölgede artan askeri varlık projeye karşı Bugti ve Marri aşiretleri gibi büyük Beluci aşiretlerinin tepkisine neden olmuştur. ${ }^{14}$ Belucistan valisi Abdul Kadir Baloch 2003'de aşiret tepkilerini karşılıklı diyalog yoluyla çözmeye çalıştıysa da bu yaklaşım Müşerref tarafından benimsenmemiş, Baloch kısa süre sonra rüşvet aldığı ve aşiret reislerinin etkisi altında olduğu gerekçeleriyle görevinden azledilmiştir. ${ }^{15}$

Sosyal, ekonomik ve politik endişeleri isyana çeviren kıvılcım, 3 Ocak 2005 gecesi Dera Bugti bölgesindeki Sui doğalgaz fabrikasında çalışan Dr. Shazia Khalid’in evinde maskeli bir saldırganın

101980 öncesi Belucistan isyanları hakkında daha fazla bilgi için bkz. Selig S. Harrison, In Afghanistan's Shadow: Baluch Nationalism and Soviet Temptations, New York, Carnegie Endowment for International Peace, 1981.

11 Owen Benneth Jones, Pakistan: Eye of the Storm, New Haven, Yale University Press, 2002, s.69.

12 Syed Fazl-e-Hayder, "Higher Poverty in Balochistan", Dawn, 6 Şubat 2006, http://www.dawn.com/news/177446/ higher-poverty-in-balochistan (Erişim Tarihi: 8 Mart 2015).

13 International Crisis Group (ICG) , "Pakistan: The Worsening Conflict in Balochistan", Asia Report, No.119, 2006, http://www.crisisgroup.org/ /media/Files/asia/south-asia/pakistan/b69_pakistan_the_forgotten_conflict_in_ balochistan.pdf/ (Erişim Tarihi: 16 Mart 2015); Apama Pande, Explaining Pakistan's Foreign Policy: Escaping India, $\overline{\mathrm{N} e w}$ York, Routledge, 2011, s.128.

14 ICG, "Pakistan", s.15; Frederic Grare, "Pakistan: The Resurgence of Baluch Nationalism”, Carnegie Papers, No.65, January 2006, http://carnegieendowment.org/files/CP65.Grare.FINAL.pdf (Erişim Tarihi: 11 Mart 2015).

15 Robert G. Wirsing, Baloch Nationalism and the Geopolitics of Energy Resources: The Changing Context of Separatism in Pakistan, Carlisle, Strategic Studies Institute, U.S. Army War College, 2008, s.33-34. 
tecavüzüne uğraması olmuştur. Şüphelinin bir asker olması ve ordunun yerel polise şüpheliyi sorgulama izni vermemesi sonucunda Bugti aşiretinin üyeleri fabrikaya roket ve silahlarla saldırmış, Müşerref rejimi de buna karşlık bölgeye tanklar ve helikopterlerle desteklenen 4500 kişilik bir askeri güç göndermiştir. ${ }^{16}$ Askeri operasyon çok sayıda sivilin hayatına mal olmuş, sadece 17 Mart tarihinde çoğu kadın ve çocuk 43 sivil "güvenlik güçlerinin ayrım gözetmeyen ve aşırı güç kullanımı” sonucu hayatını kaybetmiştir. ${ }^{17}$ Çatışmalara rağmen bu dönemde sivil politikacılar inisiyatif almışlar ve General Müşerref' in kontrolü altındaki Pakistan Müslüman Ligi yöneticileri Bugti aşireti lideri Akbar Bugti ile 24 Mart'ta sorunun siyasi yollardan çözümü yönünde anlaşmışlardır. ${ }^{18}$ Bu gelişme neticesinde Nisan-Haziran ayları arasında Beluci saldırıları durmuştur.

Bu görüşmeyi başka bir sivil girişim izlemiş, Haziran ayında Belucistan sorunları hakkında bir Pakistan Parlamentosu komitesi toplanmıştır. Komite toplantılarında Belucistan bölgesinden katılan siyasi partiler yerel nüfusun politik, ekonomik ve sosyal sorunları çözülünceye kadar Gvadar projesinin durdurulmasını, bölgede sivil ve askeri yetkililere toprak tahsisinin sona ermesini, çatışmalar sonucu bölgede artan sayıdaki askeri tesis inşaatının durmasını, askeri operasyonların sona erdirilmesini, askeri kontrol noktalarının kaldırılmasını, bölgeden edinilen doğalgaz gelirlerinin eyaletin fakir konumu dikkate alınarak dengeli bir biçimde paylaştırılmasını ve Gvadar projesinde Belucilerin daha aktif katılımını sağlayacak bir mekanizmanın kurulmasını talep etmişlerdir. Komitenin hazırladığı rapor bu taleplere makul ölçülerde cevap vermiş ve çatışmaların barışçıl yoldan çözümü için bir yol haritası oluşturulmuştur. ${ }^{19}$

$\mathrm{Bu}$ sivil girişimin attığı adımlara Müşerref ve Pakistan ordusu mesafeli yaklaşmış ve ilk krizde atılan adımlar tersine çevirmiştir. Müşerref, 25 Aralık'ta Marri aşiretinin kontrolü altındaki Kohlu bölgesine gerçekleştirdiği ziyaret sırasında kimliği belirsiz kişilerce düzenlenen başarısız bir roket saldırısına maruz kalmış, ordu içindeki şahin kanat saldırıyı takiben politik tavizlerin sona erdirilerek başta Bugti, Mengal ve Marri olmak üzere Beluci aşiretlerine karşı askeri güç kullanılması gerektiğini savunmuşlardır. Bunun üzerine bölgeye 25,000 kişilik bir askeri güç sevk edilmiş, Beluci köylerinin bombalanması sonucunda çoğu çocuk ve kadın 215 sivil hayatını kaybetmiştir. ${ }^{20}$ Askeri güç Dera Bugti bölgesinde de kullanılmış, nüfusun yaklaşık yüzde 85 'i orduya bağlı Sınır Birlikleri’nin ölçüsüz şiddeti yüzünden bölgeden göç etmiştir. ${ }^{21}$ Kısacası roketle gerçekleştirilen tek bir saldırı ordunun diyalog yolunu bir kenara bırakarak Belucilere karşı topyekûn bir savaş başlatmasına yetmiştir.

Müşerref rejiminin Beluci politikası Aralık 2005'ten itibaren tamamen askeri bir görünüm almıştır. Rejim etnik sorunları ve talepleri göz ardı etmiş ve bölgedeki şiddeti Hindistan ve Afganistan destekli birkaç aşiret liderinin başlattığı asayiş ve düzen sorunu olarak tanımlamıştır. Resmi görüş aşiret liderlerinin modernizasyona karşı olduğuna vurgu yapmış ve sorunun tek çözüm yolunun devletin gücünü bölgede göstererek aşiret liderlerini “düzeltmek” olduğunu belirtmiştir. ${ }^{22}$ Müşerref rejimi, devletin kuruluşundan

16 “Pakistan's Gas Fields Targeted as Baluch Rebels Avenge Rape”, The Guardian, World News Connection, 21 Şubat 2005 (Erişim Tarihi: 8 Mart 2015).

17 Human Rights Commission of Pakistan, “Conflict in Balochistan: HRCP Fact-Finding Missions”, 2006, http://hrcpweb.org/publication/book/conflict-in-balochistan/ (Erişim Tarihi: 12 Mart 2015).

18 “'Balochistan Deadlock Ends,' Says PML Leader: Shujaat Meets Bugti”, Dawn, 25 Mart 2005, http://www.dawn.com/ news/1067432, (Erişim Tarihi: 13 Mart 2015).

19 "Report of the Parliamentary Committee on Balochistan", http://www.senate.gov.pk/uploads/documents/1308 267066_685.pdf, (Erişim Tarihi: 12 Mart 2015), s.107-108.

20 Selig S. Harrison, “Pakistan's Costly 'Other War”, Washington Post, 15 Şubat 2006, http://www.washingtonpost.com/ wp-dyn/content/article/2006/02/14/AR2006021401767.html, (Erişim Tarihi: 14 Mart 2015).

21 Human Rights Commission of Pakistan, "Conflict in Balochistan”, s.14.

22 Jones, Pakistan, s.71. 
beri varlığını koruyan temel sosyal ve siyasi sorunları basite indirgeyen bu anlayışına paralel biçimde aşiret liderlerini imha etmeye yönelik bir yaklaşım sergilemeye başlamıştır. Bir iddiaya göre Ağustos 2006 başında Müşerref ve bazı üst düzey generaller bölgenin petrol ve gaz kaynaklarını daha kolay kontrol etmek amacıyla "bütün sorun çıkaranları ortadan kaldırmak" konusunda anlaşmışlar, ${ }^{23}$ bu politikanın ilk kurbanı ise 26 Ağustos’ta saklandığı bir mağarada bombalanan Akbar Bugti olmuştur. Bugti’nin öldürülmesi Belucistan sorununu çözmemiş, bir yandan eyalette geniş katılımlı protestoların yaşanmasına neden olurken diğer yandan da sorunun "birkaç aşiret lideri sorunu” olmadığını kanıtlarmışçasına 126 yıl sonra ilk defa 90 aşiret liderinin katılımıyla Jirga toplanmıştır. ${ }^{24}$ Katılımcılar, Uluslararası Adalet Divanı'nın soruna müdahil olmasını talep ederken, ${ }^{25}$ Müşerref'i destekleyen dini partiler dahi devleti askeri müdahalede bulunmak yerine diyalog kurmaya davet etmiştir. ${ }^{26}$

Müşerref rejimi tepkilere rağmen aşiret liderlerini hedef almayı sürdürmüş, Bugti’nin öldürülmesinden birkaç ay sonra Mengal aşireti lideri Aktar Mengal vatana ihanet suçlamasıyla tutuklanmış ve hem askeri istihbarat birimlerince sorgulanmasında hem de duruşma sürecinde insan haklarını ihlal eden şartlar altında tutulmuştur. ${ }^{27}$ Aşiret liderlerini imha politikasından Marri aşireti de payını almış, Navabzade Balach Marri Kasım 2007'de Afganistan'da bazılarına göre Pakistan güvenlik güçlerince öldürülmüştür. ${ }^{28} \mathrm{Bu}$ imha politikası sadece 1970 'lerden beri devletle bölge arasındaki ilişkilerde arabuluculuk yapan politikacı kimlikli aşiret liderlerini hedef alarak kitlesel gösterilere yol açmamış, aynı zamanda pragmatik politikacıların yerini daha militan Beluci grupların almasına neden olmuştur.

Müşerref rejimi bu dönemde aşiret liderlerini hedef almanın yanı sıra binlerce Beluci'yi de devletin keyfi tutuklama, alıkoyma, işkence ve yargısız infaz politikalarına maruz bırakmıştır. Dönemin İçişleri Bakanı Aftab Ahmad Sherpeo sadece 2005 yılında 4,000'den fazla Beluci'nin tutuklandığını açıklamış, çatışmaların yoğunlaşmasıyla insan hakları ihlalleri rutin bir hale dönüşmüştür. Özellikle güvenlik güçlerinin elinde meydana gelen politik kaybolmaların sayısı her yıl artmış, Müşerref rejiminin sona ermesinin ardından Belucistan'da toplam 1,102 kişinin kayıp olduğu açıklanmıştır. ${ }^{29}$ Politik kayıplara yönelik olarak Yüksek Adalet Divanı Başkanı Muhammed İftikhar Chaudhry yargısal bir girişimde bulunarak güvenlik güçlerinin elindeki Belucilerin isimlerinin açılanması ve bunların serbest bırakılması için uğraşsa da bu çabası ancak az sayıda Beluci’ye özgürlüğünü getirmiştir. ${ }^{30}$ İnsan Hakları İzleme Örgütü raporuna göre Müsserref'in Mart 2007'de Chaudhry’i görevinden almasında yargının askeri yetkilileri politik kayıplarla ilgili olarak sorgulaması büyük rol oynamıştır. ${ }^{31}$

23 ICG, "Pakistan: The Forgotten Conflict in Balochistan", Asia Briefing, No.69, 2007, http://www.crisisgroup.org/ / media/Files/asia/south-asia/pakistan/b69_pakistan_the_forgotten_conflict_in_balochistan.pdf/ (Erişim Tarihi: 16 Mart 2015), s.2.

24 Afganistan ve Pakistan'da bir çeşit danışma meclisi işlevi gören ve aşiretler arasındaki sorunları İslami prensiplere göre barışçıl yolla çözme ilkesiyle hareket eden geleneksel konsey.

25 Ahmar Mustikhan, "Musharraf's Hidden War", New Internationalist, No. 396, http://newint.org/columns/ currents/2006/12/01/pakistan/ (Erişim Tarihi: 16 Mart 2015).

26 Carlotta Gall, “Tribal Leader's Killing Incites Riots in Pakistan”, New York Times, 28 Ağustos 2006, http://www.nytimes. com/2006/08/28/world/asia/28pakistan.html?_r=0 (Erişim Tarihi: 17 Mart 2015).

27 “HRCP Says Mengal Kept in an Iron Cage”, Dawn, 9 Ocak 2007, http://www.dawn.com/news/227065/hrcp-saysmengal-kept-in-iron-cage (Erişim Tarihi: 17 Mart 2015).

28 Saleem Shahid, "Balach Marri Killed: Violence in Quetta, Schools Closed”, Dawn, 22 Kasım 2007, http://www.dawn. com/news/277009/balach-marri-killed-violence-in-quetta-schools-closed (Erişim Tarihi: 17 Mart 2015).

29 “Over 1,100 People Missing in Balochistan, Says Malik”, Dawn, 28 Ağustos 2008, http://www.dawn.com/news/318655/ over-1100-people-missing-in-balochistan-says-malik (Erişim Tarihi: 17 Mart 2015).

30 ICG, "Pakistan: The Forgotten Conflict", s.4-5.

31 Human Rights Watch, ““We Can Torture, Kill, or Keep You for Years”: Enforced Disappearances by Pakistan Security 
Rejimin düşünce yapısı artan askeri ve güvenlik önlemlerinin yanında politik stratejilerde de kendisini göstermiştir. Müşerref rejimi, Beluci gruplarla diyalog kurmak ve bölge halkının ekonomik, sosyal ve politik kaygılarına cevap vermek yerine İslam’ı kullanarak ve böl-ve-yönet stratejisi takip ederek Beluci milliyetçiliğini yok etmeyi planlamıştır. General Müşerref, General Ziya rejimine benzer biçimde seküler Beluci milliyetçiliğine karşı bölgeyi İslamlaştırmaya yönelmiş, medrese sayısı hızla artmış ve Diyanet İşleri Başkanlığı eyalet bütçesinde Eğitim Bakanlığı'ndan altı kat daha fazla pay almıştır. ${ }^{32}$ İslamlaştırma politikası seküler Belucileri devlete daha fazla yabancılaştırmakla kalmamış, aynı zamanda sayısı artan medreseler Ziya ve Müşerref dönemlerinde Afganistan'dan bölgeye göç eden Peştun nüfusunun kontrolünde olduğu için hem bölgedeki politik dengeleri etkilemiş hem de Belucistan'da daha önce görülmeyen, azınlıkta olan Şii gruplara yönelik mezhepsel şiddeti bölge ile tanıştırmıştır.

Bu politika ile bağlantılı olarak askeri rejim böl-ve-yönet stratejisini etkili olarak kullanmıştır. Beluci-Peştun ayrımında Müşerref bölgede Peştun gruplarla ittifak yapmış, rejimin desteğini alan Peştun dini partiler 2002 seçimleriyle bölgede ilk defa iktidara gelmişlerdir. Eyalet yönetimindeki kritik önemdeki pozisyonlar dini partilere verilmiş, karşılığında bu partiler merkezin modernizasyon projelerine ve askeri operasyonlarına ses çıkarmamışlardır. Aynı zamanda rejim Beluciler arasındaki ihtilaflardan yararlanmak suretiyle böl-ve-yönet stratejisini uygulamıştır. Örneğin, Akbar Bugti’nin öldürülmesinden sonra Pakistan ordusu rejime muhalif aşiret mensuplarına karşı Bugti’nin büyük oğlunu koruması altına alarak ve ona destek vererek Bugti aşiretini "bölüp yönetmede oldukça başarılı olmuştur." ${ }^{33}$ Belucistan içindeki ideolojik, etnik, aşiret temelli ve aşiret-içi bölünmeler rejimin sorunu diyalog yoluyla çözme konusundaki isteksizliğiyle birleşerek askeri ve güvenlik önlemlerini bölgede tek politika haline getirmiştir.

\section{Zerdari Döneminde (2008-2012) Belucistan Politikası}

Belucistan çatışması tüm şiddetiyle devam ederken Müşerref, kendisinden önceki askeri liderler gibi popülaritesini yitirmeye başlamıştır. 2007 yılında cumhurbaşkanlığı döneminin sonuna yaklaşırken, Müşerref üniforma ile tekrar devlet başkanı seçilememe endişesiyle Kasım ayında anayasayı askıya almış ve yargı üzerinde baskı uygulamaya başlamıştır. Ama bu yaklaşım ters tepmiş, kamuoyunun ardından ordunun da desteğini yitiren Müşerref önce Genelkurmay Başkanlığı’ndan istifa etmiş, Şubat 2008'de de seçimlere gitmek zorunda kalmıştır. Benazir Buttónun seçimler öncesinde suikaste uğramasının da etkisiyle Butto'nun kocası Asıf Ali Zerdari’nin liderliğindeki Pakistan Halk Partisi seçimleri kazanmış, Ağustos 2008'de ise Müşerref kendisine yönelik Yüce Divan tehdidi sebebiyle başkanlıktan istifa etmiş ve Londra'ya sürgüne gitmiştir. Bu hızlı değişim sürecinin sonunda Zerdari devlet başkanlığına gelirken, Yusuf Rıza Gilani başbakan olmuş, genelkurmay başkanlığına ise General Eşref Pervez Kayani oturmuştur. Sivil rejime geçiş önceki değişimler gibi ordunun Pakistan politikasındaki rolünü etkilememiş ve bu durum kendini Belucistan politikası üzerinde de açıkça göstermiştir. Bu dönemde Zerdari/Gilani iktidarının bazı sivil girişimlerine rağmen Müşerref döneminin politikaları olan politik kaybolmalar, işkence, yargısız infazlar, "öldür-ve-at" ve böl-ve-yönet politikaları daha şiddetli biçimde sürdürülmüştür. Pakistan ordusu ve ona bağlı güvenlik güçleri devletin Belucistan politikasında temel belirleyici olmuştur.

Pakistan Halk Partisi Şubat 2008'de iktidara geldiğinde Belucistan sorununa olumlu bir takım jestlerle yaklaştı. Seçimlerin ardından parti yetkilileri Belucilere karşı yapılan zulüm ve adaletsizlikler

Forces in Balochistan”, 2011, http://www.hrw.org/sites/default/files/reports/pakistan0711WebInside.pdf (Erişim Tarihi: 17 Mart 2015).

32 Grare, "Pakistan", s.1.

33 Anatol Lieven, Pakistan: A Hard Country, Londra, Allen Lane, 2011, s.351. 
için alenen özür dilemiş ve karşılıklı saygıya dayanan ve eski yaraları iyileştirecek yeni bir sürecin sözünü vermişlerdir. Parti bölgedeki askeri operasyonların durması ve bütün siyasi tutukluların salıverilmesi konusunda söz vermiş ve Aktar Mengal Mayıs ayında serbest bırakılmıştır. Zerdari, partisinin diyaloğa açık olduğunu ve dağdaki direnişçilerle bile konuşabileceğini ifade ederken, 1973 Anayasası’nın öngördügü bölgesel özerkliğin tesisinin sağlanacağını da belirtmiştir. ${ }^{34}$

$\mathrm{Bu}$ açıklamalara paralel olarak yeni hükümet Belucilerin problemlerine çözüm getirmek için acilen bir parlamento komitesi kurmuştur. Müşerref' in devlet başkanlığından ayrılışı çözüm çabalarını hızlandırmış, Ekim 2008'de hükümet Belucistan sorunu hakkında bir yol haritası sunmuştur. Yol haritası Beluci aydınları da dâhil olmak üzere ülkedeki bütün politik unsurların katılacağı bir Jirga'nın toplanmasını öngörürken kaynakların dağılımının eşit şekilde yapılması gerektiğini belirtmiş ve Bugti, Mengal ve Marri aşiretlerinin üyeleri de dâhil olmak üzere 830 siyasi mahkûmun salıverilmesi yönünde çağrı yapılmıştır. Yeni devlet başkanı Zerdari, Müşerref'in aksine, Belucistan probleminin terör ya da ayrılıkçı bir sorun değil, politik bir mesele olduğunu belirtmiştir. ${ }^{35}$

Diğer yandan parlamento komitesi 18 aylık bir çalışmanın ardından Kasım 2009'da kısaca "Belucistan Paketi” denilen 39 maddelik bir reform paketini hazırlamıştır. Oldukça kapsamlı olan bu çalışma; bölgesel özerkliğin tesisini, ekonomik gelirlerin paylaşımında bölgenin geri kalmışlığını göze alacak bir yapının sağlanmasını, siyasi mahkûmların salıverilmesini, siyasi diyaloğun kurulmasını, siyasi sürgünlerin ülkeye dönüşünün sağlanmasını, yerel yönetim reformunu, bölgede askeri operasyonların ve askeri tesis yapımının durmasını, Bugti’nin ölümü ve kaybolan insanlarla ilgili komisyon kurulmasını, Sınır Birlikleri’nin bölgedeki rolü konusunda yeni düzenlemeler yapılmasını, Gvadar'daki toprak alımlarını inceleyecek bir yargısal mekanizma kurulmasını, doğalgaz gelirlerinin adil paylaşımını, bölgesel projelerde daha aktif Beluci katılımını ve 1954-1991 yılları arasındaki geçmiş gaz alımları için Belucistan’a 12 yılda 120 milyar rupi ödenmesini talep ederek adaletsizliğin giderilmesini sağlamayı amaçlamıştır. ${ }^{36}$

Belucistan Paketi’ni takiben Aralık ayında eyaletin merkezi hükümetten aldığı ekonomik gelirlerin dağılımındaki payı arttırılmış ve anayasada yapılan değişiklikle devlet başkanının yetkileri ulusal ve bölgesel meclisler lehine azaltılmıştır. Yine de bütün bu girişimler bölgedeki gerilimi azaltmaya ve çatışmaları sona ermeye yetmemiştir. Ayrılıkçı Beluci gruplar atılan adımları "sadaka" ve hatta "şaka" olarak tarif ederken ${ }^{37}$ hükümet paketi uygulama aşamasında yavaş kalmış, Mart 2011'e kadar paketin ancak dörtte biri hayata geçirilmiştir. Daha da önemlisi, doğalgaz dağıtımında Belucistan’a öncelik verilmesi, siyasi sürgünlerin ülkeye geri dönmesi, Beluci gruplarla siyasi diyalog, Sınır Birlikleri’nin sivil kontrolü ve daha birçok kritik konuda adım atılmamıştır. ${ }^{38}$

Sivil yönetimin yavaşlı̆̆ ve militarist Beluci grupların uyuşmazlığı çatışmaların devamında rol oynasa da, sorunun çözüme kavuşmamasında en önemli faktör Pakistan ordusunun sivillerin kontrolü

34 Raja Asghar, "PPP Apologises to Balochistan for 'Excesses': Pledge of Maximum Provincial Autonomy”, Dawn, 25 Şubat 2008, http://www.dawn.com/news/290904/ppp-apologises-to-balochistan-for-excesses-pledge-of-maximumprovincial-autonomy (Erişim Tarihi: 2 Nisan 2015).

35 Inamullah Khattak, "Roadmap to Resolve Balochistan Tangle Unveiled”, Dawn, 27 Ekim 2008, http://www.dawn.com/ news/327299/roadmap-to-resolve-balochistan-tangle-unveiled (Erişim Tarihi: 2 Nisan 2015).

36 Shahid Hamid, “The Aghaz-e-Huqooq-e-Balochistan Package: An Analysis”, PILDAT Background Paper, 2009, s. 17-20, http://www.pildat.org/publications/publication/balochistanconflict/PILDATBalochistanPackageAnalysis101209. pdf (Erişim Tarihi: 3 Nisan 2015).

37 Bari Baloch, “Nationalists Reject Package as Charity”, Nation, 25 Kasım 2009, http://nation.com.pk/politics/25Nov-2009/Nationalists-reject-package-as-charity (Erişim Tarihi: 3 Nisan 2015).

38 Zahid Gishkori, “Aghaz-e-Haqooq-e-Balochistan: Reform Package Stopped in Its Tracks”, 7 Mart 2011, http://tribune. com.pk/story/128835/aghaz-e-haqooq-e-balochistan-reform-package-stopped-in-its-tracks/ (Erişim Tarihi: 3 Nisan 2015). 
dışında sürdürdüğü Belucistan politikası olmuştur. Sivil rejimin sorunu güç kullanmadan çözme çabalarına karşı Pakistan ordusu Müşerref dönemi askeri politikalarına ara vermeden devam etmiş, bazı politikacılara göre ufak eyaletlerin haklarına inanmayan ordu ve istihbarat birimlerindeki şahinler Belucistan'daki uzlaşma sürecini sabote etmek için aktif olarak çalışmışlardır. ${ }^{39}$ General Kayani’nin konuşmalarında eyalette sivillerin yetkili olduğunu söylemesine ve askeri operasyonların bölgesel yönetimin onayı olmadan gerçekleşmeyeceğini belirtmesine rağmen bu dönemde Belucistan'da asıl söz sahibinin ordu olduğu konusunda şüphe yoktu. Örneğin, Ekim 2009 raporunda Pakistan İnsan Hakları Komisyonu Belucistan konusunda karar-alma mekanizmasının hala Şubat 2008 seçimlerinden önceki birimlerde, yani orduda olduğunu belirtmiştir. ${ }^{40}$ Benzer şekilde Pakistan'la ilgili 2010 İnsan Hakları raporunda Amerikan Dışişleri Bakanlığı, ülkedeki güvenlik güçlerinin sivil yetkililere rapor vermediğini ve hükümetten bağımsız hareket ettiklerini ifade etmiştir. ${ }^{41}$ İnsan Hakları İzleme Örgütü de 2011 raporunda aynı sonuca varmış, güvenlik güçlerinin Müşerref dönemindeki ayrıcalıklarına sahip olduğunu, yargı kurumlarının ve üst düzey hükümet yetkililerinin kontrolü dışında hareket ettiklerini saptamıştır. ${ }^{42}$

Siyaset üzerindeki değişmeyen etkisiyle Pakistan ordusu, sivil yöneticilerin politik çözüm arama çalışmalarına rağmen Müşerref dönemi politikalarını sürdürmüştür. Örneğin, önde gelen Beluci milliyetçilerini infaz operasyonları tüm hızıyla devam etmiş, çok sayıda Beluci politikacı, entelektüel, aktivist ve öğrenci lideri güvenlik güçlerinin hedefi olmuştur. Şubat 2009'da devletin Belucistan politikasına eleştirileriyle bilinen şair ve düşünür Jan Mohammad Dashti’ye suikast düzenlenmiş, iki ay sonra önde gelen Beluci politikacıları Ghulam Mohammad Baloch, Lala Munir ve Sher Mohammad Baloch kimliği belirsiz kişilerce kaçırıldıktan sonra infaz edilmişlerdir. ${ }^{43}$ İnfaz politikaları 2010 senesinde şiddetini arttırmış, Temmuz ve Ekim ayları arasında 40'tan fazla Beluci politikacı ve aktivist işkence görüp öldürülmüştür. ${ }^{44}$ Mart ve Nisan 2011'de bu sefer Pakistan İnsan Hakları Komisyonu adlı sivil toplum örgütünden Naeem Sabir ve Siddique Eido Sınır Birlikleri üniformalı kişilerce kaçırıldıktan sonra öldürülmüşlerdir. ${ }^{45}$ Ocak 2012'de ise Beluci Cumhuriyetçi Partisi lideri Nawabzada Brahamdagh Bugti'nin kızı İsviçre'den siyasi mültecilik hakkı kazanan babasına uyarı amacıyla kimliği belirsiz kişilerce öldürülmüştür. ${ }^{46}$ Her ne kadar çoğu saldırının failleri belli olmamışsa da Pakistan ordusuna bağlı güvenlik güçlerinin ve onların "ölüm timleri”nin saldırıların arkasında olduğuna dair hem ülkede hem de uluslararası aktörler arasında yaygın bir inanış vardı. ${ }^{47}$

Yine Müşerref döneminde olduğu gibi sadece önde gelen politikacılar ve aktivistler değil, çok sayıda sıradan Beluci vatandaşı da güvenlik güçlerinin hedefi olmuştur. Bu dönemde binlerce Beluci

39 Malik Siraj Akbar, “Plans to Sabotage the Balochistan Package”, 20 Ocak 2010, http://archives.dailytimes.com.pk/editorial/20Jan-2010/comment-plans-to-sabotage-the-balochistan-package-malik-siraj-akbar (Erişim Tarihi: 3 Nisan 2015).

40 Human Righs Commission of Pakistan, "Pushed to the Wall: Report of the HRCP Fact-Finding Mission to Balochistan", s. 5, 2009, http://hrcp-web.org/publication/book/pushed-to-the-wall/ (Erişim Tarihi: 6 Nisan 2015).

41 United States Department of State, “2010 Human Rights Report: Pakistan”, 2011, s.1, http://www.state.gov/ documents/organization/160472.pdf (Erişim Tarihi: 6 Nisan 2015).

42 Human Rights Watch, "We Can Torture", s.5.

43 “Who Killed Baloch Leaders?”, Dawn, 25 Mayıs 2009, http://www.dawn.com/news/965267/who-killed-the-balochleaders (Erişim Tarihi: 6 Nisan 2015).

44 Amnesty International, "Pakistan: Investigate Murder and Torture of Baloch Activists”, 2010, http://www.amnesty.org. au/news/comments/23986/ (Erişim Tarihi: 10 Nisan 2015).

45 Human Rights Commission of Pakistan, "Hopes, Fears and Alienation in Balochistan”, 2012, http://hrcp-web.org/ publication/book/hopes-fears-and-alienation-in-balochistan/ (Erişim Tarihi: 6 Nisan 2015).

46 United States Department of State, "Pakistan 2012 Human Rights Report”, 2013, http://www.state.gov/documents/ organization/204621.pdf (Erişim Tarihi: 10 Nisan 2015).

47 Unrepresented Nations and Peoples Organization, "Balochistan: Former Senator Condemns Tactics of Pakistani Army”, 2010, http://unpo.org/article/11346 (Erişim Tarihi: 10 Nisan 2015); Amnesty International, “Pakistan: Investigate Murder”. 
sadece Beluci milliyetçi partilerine ve gösterilerine katıldıkları için güvenlik güçlerince kaçırıldıktan sonra ordu ve istihbarat birimleri tarafindan yönetilen hücrelerde işkenceden geçirilmiştir. Bunlardan şanslı olanları belli bir dönem sonra serbest bırakılmış fakat azımsanmayacak bir kısmı yargısız infaza uğramıştır. Kaybolan Belucilerin Sesi adlı sivil toplum örgütüne göre sadece sivil rejim döneminde “öldür-ve-at” (kill-and-dump) olarak da bilinen bu politika sonucu 400'den fazla Beluci öldürülmüş ve cesetleri eyaletin çeşitli yerlerine bırakılmıştır. ${ }^{48}$ Eylül 2013'de bir devlet raporu 2010'dan itibaren eyalette 592 adet işkenceden geçirilmiş ceset bulunduğunu belirtmiştir. ${ }^{49}$ Temmuz 2012 raporunda ise Pakistan İçişleri Bakanlı̆̆ eyaletteki anarşik durum hakkında daha karamsar bir tablo sunmuş ve 2010'dan itibaren Belucistan'da en az 868 kişinin öldürüldügünü, 619 kişinin kaçırıldığını ve 2.390 kişinin kaybolduğunu bildirmiştir. ${ }^{50}$

Ordu mensupları Belucilerin kaçırılmalarında ve infaz edilmelerinde kendi kurumlarına yönelik suçlamaları reddetmişlerdir. Örneğin Belucistan'daki Sınır Birlikleri’nin komutanı olan Tümgeneral Ulah Khan Niazi kaçırma olaylarının Sınır Birlikleri üniforması giyen militanlar tarafından yapıldığını ve amacın Pakistan ordusunun ismini karalamak olduğunu ifade etmiştir. ${ }^{51}$ Güney Kuvvetleri Komutanı Korgeneral Javed Zia da ordunun, Sınır Birlikleri’nin ve istihbarat birimlerinin öldür-ve-at politikası uyguladığı iddialarını reddetmiştir. ${ }^{52}$ Fakat ordunun insan hakları ihlalleri konusundaki kötü sicili, farklı sivil toplum örgütlerinin raporları, kaçırılanların ve kurban ailelerinin ifadeleri, kaçırma olaylarının askeri merkezlere yakın yerlerde yapılması, faillerin kullandıkları araçlar ile gittikleri rotalar ve ordunun Uluslararası Kızıl Haç örgütü gibi kurumların tutukevlerini incelemesine izin vermemesi gibi veriler Pakistan ordusunun Belucistan'daki kaçırma ve infaz politikalarında rolünü şüphe birakmayacak kadar şekilde ortaya koymuştur.

İnsan hakları kuruluşları ve Beluci politikacılar kaçırma ve infaz politikalarında ordunun rolünün incelenmesi için hükümete sıklıkla çağrıda bulunmuşlardır. Pakistan hükümeti bu konuda bazı adımlar atsa da bu adımlar genel olarak sonuç üretememiştir. Örneğin Karaçi ve Belucistan'daki ölümleri incelemek üzere Din İşleri Bakanı Syed Khursheed Ahmed Shah başkanlığında kurulan komiteye konuşan ordu mensupları Belucistan sorununu hükümetin hataları ve Hindistan desteği üzerinden açıklamaya çalışmış, Sınır Birlikleri’nin kaçırma ve infaz olaylarındaki rolünü reddetmiş ve Sınır Birlikleri olmasaydı eyaletteki durumun çok daha kötü olacağını belirtmişlerdir. ${ }^{53}$ Ordunun itirazlarına rağmen bu dönemde güvenlik güçlerinin insan hakları ihlallerinin incelenmesi için Pakistan meclisinde birçok kararname kabul edilmiş, ordunun sivillerin kontrolü altına girmesi için tavsiye raporları sunulmuştur. Değişik zamanlarda kabul edilen komite raporları ve kararnamelere rağmen olayların failleri yakalanmamış, ordu liderliğindeki güvenlik güçleri Beluci milliyetçilerini susturmak için değişik yöntemler kullanırken sivil yönetim şiddeti azaltmada başarısız olmuştur. Bu dönemde yargı mensupları da Belucistan konusunda adımlar atmaya çalışmış, Yüksek Adalet Divanı Başkanı

48 Asad Hashim, "Baloch Nationalists Fight Pakistan at Polls", 5 Mayıs 2013, http://www.aljazeera.com/indepth/ features/2013/05/201354155123504533.html (Erişim Tarihi: 10 Nisan 2015).

49 Ali Syed Shah, "Balochistan Unrest: 592 Mutilated Bodies Found in Last Three Years”, 12 Eylül 2013, http://www.dawn. com/news/1042164 (Erişim Tarihi: 10 Nisan 2015).

50 "Balochistan Violence: 868 Killed, 2390 Missing Since 2010, Says Interior Ministry”, Dawn, 1 Ağustos 2012, http:// www.dawn.com/news/738927/balochistan-violence-868-killed-2390-missing-since-2010-says-interior-ministry (Erişim Tarihi: 10 Nisan 2015).

51 Declan Walsh, "Pakistan's Secret Dirty War”, 29 Mart 2011, http://www.theguardian.com/world/2011/mar/29/ balochistan-pakistans-secret-dirty-war (Erişim Tarihi: 10 Nisan 2015).

52 "Army Condemns Killing of Missing Persons in Balochistan: General", Dawn, 22 Temmuz 2011, http://www.dawn.com/ news/645978/army-condemns-killing-of-missing-persons-in-balochistan-general (Erişim Tarihi: 10 Nisan 2015).

53 Tahir Khalil, “Civil, Military Leaders' Rift on Balochistan Widens”, 12 Şubat 2012, http://www.thenews.com.pk/ Todays-News-13-12403-Civil-military-leaders-rift-on-Balochistan-widens (Erişim Tarihi: 10 Nisan 2015). 
Muhammed İftikhar Chaudhry aynı Müşerref döneminde olduğu gibi kayıp Beluciler konusunda girişimde bulunmuştur. Chaudhry yetkililere kayıp insanlar konusunda bilgileri toplama emri vermiş ve Sınır Birlikleri ile istihbarat birimlerinin insan hakları ihlallerindeki sorumluluklarını incelemeye başlamıştır. Her ne kadar mahkeme kamuoyunun ilgisini çekmeyi ve bazı Belucilerin salıverilmesini sağlamışsa da, çoğu kayıp kişinin akıbeti meçhul kalmıştır. ${ }^{54}$

Müşerref döneminin sonrasında da güç kullanma politikasına öncelik veren Pakistan ordusu ayrıca farklı yöntemlerle Beluci milliyetçiliğini bastırmaya çalışmıştır. Örneğin Asya İnsan Hakları Komisyonu’na göre Beluci milliyetçilerinin güvenlik güçlerince kaçırılıp yargısız infaza uğraması hem Pakistan'da hem de uluslararası arenada tepki çekince Pakistan ordusu strateji değiştirmiş ve kirli işleri radikal gruplara yaptırmaya başlamıştır. Bu gruplar ordu birimleri, özellikle de meşhur Servislerarası İstihbarat (Inter-Services Intelligence) tarafından finanse edilmiş ve Sınır Birlikleri ile askeri istihbarat tarafından eğitilmiş olup karşılığında Beluci milliyetçilerini ordu adına tespit edip öldürmüşlerdir. Komisyonun raporuna göre Tehreek-e-Nefaz-e-Aman Balochistan bu örgütlerden biridir. ${ }^{55}$ Yine bazı uzmanlar Sipah-e-Sahaba, Lashkar-e-Jhangvi ve Baloch Musalla Difa Tanzeem gibi militan örgütlerin ordu koruması altında olduğunu öne sürerken bu örgütlerin eylemlerini askeri tesislerin yakınında yapmalarını, faillerin yakalanmamasını ve ordu istihbaratının olayların kovuşturmalarını engellemesini kanıt olarak öne sürmektedirler. ${ }^{56}$

Radikal örgütlere destek, ordunun geleneksel böl-ve-yönet politikasına uygundur. Gerçekten de ideolojik bölünmeler Belucistan'da güçlü ve homojen bir politik güç çıkmasını engellemiş, dini ve seküler Beluciler karşı karşıya gelirken ordu rahatlıkla milliyetçi grupları bastırmıştır. Bölgede BeluciPeştun bölünmesi tüm şiddetiyle devam etmiş, buna ilaveten mezhepsel şiddet Şii Hazaralar gibi azınlık grupları vurarak eyaletteki bölünmelerin katmanlarını artırmıştır. Yine Müşerref döneminde olduğu gibi ordu aşiretler-arası ve aşiret-içi bölünmeleri de teşvik etmiş, örneğin güvenlik güçlerine eleştirileriyle bilinen Belucistan Bakanı Aslam Raisani’ye karşı kardeşi Siraj Raisani’ye destek vermiştir. Yine Mengal aşiretinden Shafiqur Rahman Mengal'e destek vererek bu aşiretin politik gücünü sınırlamak amaçlanmıştır. Kısaca çok katmanlı bir böl-ve-yönet stratejisiyle ordu güvenlikçi anlayışını Belucistan'da devam ettirmiştir.

\section{Güç Kullanma Politikası ve Askeri Aktivizm}

Müşerref ve Zerdari döneminin yukarıdaki analizi askerlerin ve asker-kökenli yöneticilerin genel olarak Belucistan sorununa güvenlik eksenli baktıklarını ve sorunu güç kullanma yoluyla çözme yanlısı olduklarını gösterirken, sivillerin olaya daha geniş bir perspektiften baktıklarını ve diplomatik, ekonomik ve sosyal çözüm yollarını yadsımadıklarını ortaya koymaktadır. Peki, bu fark teorik olarak nasıl açıklanabilir? Bu konuda uluslararası çatışma literatüründeki askeri aktivizm görüşü bize bir ölçüde yardımcı olabilir. Askeri aktivizm görüşü genel olarak askerlerin politik sorunlarla karşılaştıklarında sivillere nazaran güç kullanmaya daha meyilli olduklarını, bu sebeple de askeri rejimlerin varlığının uluslararası çatışma ihtimalini arttırdığını ileri sürmektedir. ${ }^{57} \mathrm{Bu}$ durum iki temel

54 United States Department of State, "Pakistan 2012 Human Rights Report”, s.6.

55 Asian Human Rights Commission, "Pakistan: Army Creates an Organization to Kill Intellectuals and Activists in Balochistan, in the Name of Peace”, 2012, http://www.humanrights.asia/news/ahrc-news/AHRC-STM-005-2012 (Erişim Tarihi: 12 Nisan 2015).

56 Frederic Grare, "Balochistan: The State versus the Nation”, Carnegie Papers, April 2013, http://carnegieendowment. org/files/balochistan.pdf (Erişim Tarihi: 6 Nisan 2015).

57 Bu teorinin karşısında askeri tutuculuk (military conservatism) adı verilen ve askerlerin güç kullanma konusunda sivillere nazaran daha isteksiz olduklarını ve savaşların hırslı politikacıların eseri olduğunu savunan bir görüş de vardır. Askeri 
faktörle açıklanmaktadır. İlk olarak, askeri çatışmaların bazı maddi ve manevi faydalar sağlayacağı inancından hareketle kurumsal ve kişisel çıkarların askerleri daha saldırgan politika tercihlerine yönelttiği savunulmaktadır. Kişisel düzeyde savaşlar zafer ve heyecan duygularını beraberinde getirdiği gibi askerlere politik kariyerin kapılarını da açabilmektedir. Kurumsal düzeyde ise savaşlar ordunun devlet bütçesindeki payını arttırırken, aynı zamanda savaş tecrübesi, yeni taktiklerin geliştirilmesi ve teknolojik silahların sahada deneyimi gibi birçok fayda getirebilmektedir. Son olarak, savaş durumu ordunun politika yapım sürecindeki rolünü arttırarak kurumsal ve kişisel fayda sağlayabilmektedir. ${ }^{58}$

Askeri aktivizm görüşünün askerlerin güç kullanma eğilimini açıklamak için vurguladığı ikinci faktör ise askeri düşünce yapısıdır. Bu argümana göre, askerler askeri okula adım attıkları günden itibaren farklı bir sosyalleşme sürecinden geçmektedirler. Askeri okullar ve kışlalar askerleri sivil toplumdan uzun bir süreliğine ayırırken, askeri eğitim temel kaygısı ulusal güvenlik olan tek tip bireyler meydana getirmektedir. Daha da önemlisi, bu eğitimin empoze ettiği düşünceler, normlar ve değerler bireyde kalıcıdır. Cohen'in ifade ettiği gibi, ordular "üyelerinin inançlarına hayat boyu biçim veren kurumlardır" ${ }^{99}$ Askeri aktivizm görüşüne göre, kışlalardaki sosyalleşme süreci ve askeri eğitim askerleri güç kullanmaya daha meyilli yapan belli bir düşünce yapısı yaratmaktadır.

$\mathrm{Bu}$ düşünce yapısına göre, askerler realist, karamsar ve temkinli olmak zorundadır. Askeri eğitim temel olarak savaş kazanmayı, savaş meydanında hayatta kalmayı ve ülkenin sınırlarını ve halkın güvenliğini dış tehditlerden korumayı amaçlamaktadır. Bu amaçlara ulaşmada yapılacak herhangi bir hatanın büyük sonuçları olacağından bir asker her zaman en kötü senaryo üzerinden hareket etmek mecburiyetindedir. Asker düşmanın niyetleri ve kapasitesi konusunda kuşkucu olmalı ve hayatta kalmak istiyorsa silah arkadaşı haricinde kimseye güvenmemelidir. Başka bir deyişle, asker "Hobbesvari bir insan” olmalı, "bireyin içindeki iyi ve kötü arasında kötüyü vurgu[lamalıdır]”. 60

Askeri aktivizm açısından bu karamsarlığın sonucu askerlerin politik problemleri çözmede güç kullanma politikasına ağırlık vermesidir. Sechser'e göre, askerler ulusal güvenlik sorununu salt askeri bir problem olarak algıladıklarından, politik sorunların ekonomik, sosyal ve diplomatik yönlerine önem vermemektedir. Aksine, güvenlik tehditlerini abartmakta, önce saldırmanın avantajlarını vurgulamakta ve savaşın sonuçları bakımından iyimser bir tutum sergilemektedirler. Aldıkları eğitimin etkisiyle askerler kısa vadede sonuç getiren askeri önlemleri, tahmin edilmesi güç ve uygulaması zaman alan diplomatik adımlara tercih etmekte, düşmana verilen politik tavizleri zayıflık olarak değerlendirmektedirler. Askeri aktivizm görüşüne göre, askerler diplomatik tavizlerin var olan sorunları sadece daha kötü hale sokacağına ve askeri zaferlerin politik sorunları tamamen ortadan kaldıracağına inanmaktadırlar. ${ }^{61}$

Her ne kadar askeri aktivizm görüşü uluslararası çatışmalar için geçerli bir teorik çerçeve sunsa da, temel argümanları Pakistan ordusunun ve askerlerinin Belucistan politikasını açılamada bize yardımcı olabilmektedir. İlk olarak askeri yönetimin güç kullanma politikasının arkasında

tutuculuk teorisi genel olarak Amerika Birleşik Devletleri sivil-asker ilişkilerini inceleyen Huntington ve Betts gibi yazarlarca savunulmaktadır. Genelde Huntington'ın vurguladığı profesyonel bir ordunun varlığına dayanan bu görüş Pakistan ordusunun profesyonel olmayan niteliğinden dolayı bu çalışmada yer almamaktadır. Richard K. Betts, Soldiers, Statesmen, and Cold War Crises, Cambridge: Harvard University Press, 1977; Samuel P. Huntington, The Soldier and the State: The Theory and Politics of Civil-Military Relations, Cambridge, Belknap Press of Harvard University Press, 1985.

58 Todd S. Sechser, “Are Soldiers Less War-Prone than Statesmen?”, Journal of Conflict Resolution, Cilt 48, No.4, 2004 , s.750.

59 Cohen, The Idea of Pakistan, s.98.

60 Huntington, The Soldier and the State, s.61.

61 Sechser, "Are Soldiers Less War-Prone”, s.750-751; Jessica L. Weeks, "Strongmen and Straw Men: Authoritarian Regimes and the Initiation of International Conflict", American Political Science Review, Cilt 106, No.2, 2012, s.333. 
askerlerin önemli kişisel/kurumsal çıkarları vardır. Örneğin, Gvadar projesi ordunun Pakistan'daki tek modernleştirici güç olduğunu ispat ve askeri rejime meşruluk sağlaması bakımından önemli olduğu için projeye yönelik Beluci tepkisine ordu tarafindan şiddetle karşı konulmuştur. Aynı zamanda, Belucistan'ın konumu askeri olarak Hindistan'a karşı coğrafi derinlik sağlama ve komşu Afganistan'daki gelişmeleri etkileme bakımından kritik öneme sahip olduğundan bu bölgedeki gelişmeler ordunun kurumsal çıkarlarını güvenlik bakımından da büyük ölçüde etkileme gücüne sahip olmuştur. Son olarak, askeri yetkilerin Gvadar projesi dolayısıyla Belucistan'da kendilerine değerli toprakları tahsis etmeleri ve Beluci tepkisinin bu duruma tehdit olması devlet politikasında askerlerin kişisel çıarlarının da etkili olduğunu göstermektedir.

Öte yandan, askeri düşünce yapısı güç kullanma politikasının ardındaki psikolojiyi anlama açısından önemlidir. Askeri yetkililer aldıkları eğitimin de etkisiyle kendilerini Pakistan’ı modernize edecek tek güç olarak görürken, modernizasyon projelerinin yaratabileceği sosyal, ekonomik ve politik problemleri göz ardı etmişlerdir. Aksine, etnik şikâyetleri dış destekli birkaç aşiret liderinin propagandası olarak algılamışlar ve bunları güç kullanma yoluyla bastırma yoluna gitmişlerdir. Belucilerin sorunları geçmişte Bengallilerin yaşadığı mağduriyete aşırı derecede benzediği halde geçmişten politik dersler almamışlar, Belucilerin nüfus olarak güçsüz oluşunun da etkisiyle güç kullanma politikasının avantajına büyük önem vermişlerdir. Kısaca, askeri aktivizm görüşüne paralel olarak Belucilerin niyetlerini en kötümser şekilde algılayıp diplomasinin sorunu daha da büyüteceğine inanmışlardır. Kişisel ve kurumsal çıkarların güçlendirdiği bu psikolojinin etkisiyle ekonomik, sosyal ve politik tedbirleri es geçip Belucilere karşı kazanılacak askeri zaferin tüm sorunları çözeceğini vurgulamışlarsa da, askerlerin takip ettiği politika sorunu çıkmaz bir hale sokmuş ve bölgedeki şiddet artarak devam etmiştir.

\section{Sonuç}

Özetle, hem Müşerref hem de Zerdari döneminde Pakistan ordusu devletin Belucistan politikasının temel belirleyicisi olmuş ve süreç boyunca güç kullanımı başta olmak üzere askeri nitelikli güvenlik politikaları Pakistan'ın resmi Belucistan politikası olmuştur. Askeri rejim döneminde General Müşerref ve askeri yetkililer homojen olarak Belucilere karşı güç kullanımını savunurken siviller bölünmüş, bazıları pragmatik davranarak rejimi desteklerken bazıları da sorunu çözmek için ekonomik, sosyal ve politik önlemlerin önemine vurgu yapmıştır. 2008 yılında gerçekleşen sivil rejime geçiş ise Belucistan politikasında ciddi bir değişim getirmemiş, hükümet ve yargı mensuplarının Belucilerin sorunlarını gidermek için bazı adımlar atmasına rağmen, ordunun siyaset üzerindeki kalıcı etkisi sebebiyle Müşerref döneminin militan politikaları devam etmiştir. Bu tabloyu açıklamada askerlerin kurumsal ve kişisel çıkarları ile askeri düşünce yapısına vurgu yapan askeri aktivizm görüşü bize yardımcı olmaktadır.

Çalışma birçok açıdan literatüre katkı yapmaktadır. İlk olarak etnik çatışmalar literatürü genel olarak etnik kimliklerin ve etnik çatışmaların sivil-asker ilişkilerine etkisine vurgu yaparken, ${ }^{62}$ bu çalışma tersi bir nedenselliği yani sivil-askeri ilişkilerin etnik çatışmalara etkisini ortaya koymaktadır. İkincisi, çalışma askeri aktivizm görüşünün açıklayıcılığının altını çizerek, uluslararası çatışmaları açıklayan bu teorinin ileride etnik çatışmalara uyarlanmasının önünü açmak için küçük bir adım atmaktadır. Son olarak, gerek Türkçe gerekse uluslararası literatürde çok incelenmeyen Belucistan çatışmasının analiziyle çalışma literatüre bir katkı sunmaktadır.

62 Donald L. Horowitz, Ethnic Groups in Conflict, Berkeley, University of California Press, 1985; Irm Haleem, "Ethnic and Sectarian Violence and the Propensity Towards Praetorianism in Pakistan”, Third World Quarterly, Cilt 24, No.3, 2003, s.463-477; Stefan Lindemann, "The Ethnic Politics of Coup Avoidance: Evidence from Zambia and Uganda”, Africa Spectrum, Cilt 46, No.2, 2011, s.3-41. 


\section{Kaynakça}

Akbar, Malik Siraj. "PlanstoSabotagetheBalochistanPackage”, 20 Ocak 2010, http://archives.dailytimes.com. pk/editorial/20-Jan-2010/comment-plans-to-sabotage-the-balochistan-package-malik-siraj-akbar (Erişim Tarihi: 3 Nisan 2015).

Amnesty International. "Pakistan: InvestigateMurder and Torture of BalochActivists", 2010, http://www.amnesty.org.au/news/comments/23986/ (Erişim Tarihi: 10 Nisan 2015).

“ArmyCondemns Killing of MissingPersons in Balochistan: General”,Dawn, 22 Temmuz 2011, http://www. dawn.com/news/645978/army-condemns-killing-of-missing-persons-in-balochistan-general (Erişim Tarihi: 10 Nisan 2015).

Asghar, Raja. “PPP ApologisestoBalochistan for 'Excesses': Pledge of Maximum ProvincialAutonomy”, 25 Şubat 2008, http://www.dawn.com/news/290904/ppp-apologises-to-balochistan-for-excesses-pledgeof-maximum-provincial-autonomy (Erişim Tarihi: 2 Nisan 2015).

Asian Human RightsCommission. "Pakistan: ArmyCreates an OrganizationtoKillIntellectuals and Activists in Balochistan, in the Name of Peace", 2012, http://www.humanrights.asia/news/ahrc-news/AHRCSTM-005-2012 (Erişim Tarihi: 12 Nisan 2015).

Baloch, Bari. "NationalistsRejectPackage as Charity", 25 Kasım 2009, http://nation.com.pk/politics/25Nov-2009/Nationalists-reject-package-as-charity (Erişim Tarihi: 3 Nisan 2015).

“'BalochistanDeadlockEnds,' Says PML Leader: ShujaatMeetsBugti”, Dawn, 25 Mart 2005, http://www.dawn. com/news/1067432, (Erişim Tarihi 13 Mart 2015).

"BalochistanViolence: 868 Killed, 2390 Missing Since 2010, SaysInteriorMinistry", Dawn, 1 Ağustos 2012, http://www.dawn.com/news/738927/balochistan-violence-868-killed-2390-missing-since-2010-says-interior-ministry (Erişim Tarihi: 10 Nisan 2015).

Cohen, Stephen Philip. The Idea of Pakistan, District of Columbia, BrookingsInstitutionPress, 2004.

"HRCP SaysMengalKept in an IronCage”,Dawn, 9 Ocak 2007, http://www.dawn.com/news/227065/hrcpsays-mengal-kept-in-iron-cage (Erişim Tarihi: 17 Mart 2015).

Dugger, Celia W.“PakistaniPremierPrevails in Clashwith General”, New York Times, 20 Ekim 1998, http://www. nytimes.com/1998/10/20/world/pakistani-premier-prevails-in-clash-with-general.html (Erişim Tarihi: 29 Ocak 2015).

Fazl-e-Hayder, Syed. “HigherPoverty in Balochistan”,Dawn, 6 Şubat 2006, http://www.dawn.com/ news/177446/higher-poverty-in-balochistan (Erişim Tarihi: 8 Mart 2015).

Feldman, Herbert. "Revolution in Pakistan: A Study of theMartialLaw Administration”,The HerbertFeldmanOmnibus, New York, Oxford UniversityPress, 2001.

Feldman, Herbert. “FromCrisistoCrisis: Pakistan 1962-1969”, The HerbertFeldmanOmnibus, New York, Oxford UniversityPress, 2001.

Gall, Carlotta. “TribalLeader's Killing IncitesRiots in Pakistan”, New York Times, 28 Ağustos 2006, http://www. nytimes.com/2006/08/28/world/asia/28pakistan.html?_r=0 (Erişim Tarihi: 17 Mart 2015).

Gishkori, Zahid. “Aghaz-e-Haqooq-e-Balochistan: Reform PackageStopped in ItsTracks”,Tribune,7 Mart 2011, http://tribune.com.pk/story/128835/aghaz-e-haqooq-e-balochistan-reform-package-stopped-in-itstracks/ (Erişim Tarihi: 3 Nisan 2015).

Grare, Frederic. "Pakistan: The Resurgence of BaluchNationalism”, Carnegie Papers, No 65, January 2006, http://carnegieendowment.org/files/CP65.Grare.FINAL.pdf (Erişim Tarihi: 11 Mart 2015).

Grare, Frederic. “Balochistan: The StateversustheNation”, Carnegie Papers, April 2013, http://carnegieendowment.org/files/balochistan.pdf (Erişim Tarihi 6 Nisan 2015). 
Haleem, Irm. "Ethnic and SectarianViolence and thePropensityTowardsPraetorianism in Pakistan", Third World Quarterly, Cilt 24, No.3, 2003, s.463-477.

Hamid, Shahid. “The Aghaz-e-Huqooq-e-BalochistanPackage: An Analysis”, PILDAT Background Paper, 2009, http://www.pildat.org/publications/publication/balochistanconflict/PILDATBalochistanPackageAnalysis101209.pdf (Erişim Tarihi: 3 Nisan 2015).

Harrison, Selig S. InAfghanistan'sShadow: BaluchNationalism and SovietTemptations, New York, Carnegie Endowment for International Peace, 1981.

Harrison, Selig S. "Pakistan'sCostly 'OtherWar”, The Washington Post, 15 Şubat 2006, http://www.washingtonpost.com/wp-dyn/content/article/2006/02/14/AR2006021401767.html, (Erişim Tarihi: 14 Mart 2015).

Hashim, Asad. “BalochNationalistsFight Pakistan at Polls”, Aljazeera, 5 Mayıs 2013, http:/ /www.aljazeera.com/ indepth/features/2013/05/201354155123504533.html (Erişim Tarihi: 10 Nisan 2015).

Horowitz, Donald L. EthnicGroups in Conflict, Berkeley, University of California Press, 1985.

Human RightsCommission of Pakistan. "Conflict in Balochistan: HRCP Fact-FindingMissions”, 2006, http:// hrcp-web.org/publication/book/conflict-in-balochistan/ (Erişim Tarihi: 12 Mart 2015).

Human RightsCommission of Pakistan. "Pushedtothe Wall: Report of the HRCP Fact-FindingMissiontoBalochistan”, 2009, http://hrcp-web.org/publication/book/pushed-to-the-wall/ (Erişim Tarihi: 6 Nisan 2015).

Human RightsCommission of Pakistan. "Hopes, Fears and Alienation in Balochistan”, 2012, http://hrcp-web. org/publication/book/hopes-fears-and-alienation-in-balochistan/ (Erişim Tarihi: 6 Nisan 2015).

Human Rights Watch. “"We Can Torture, Kill, orKeepYou for Years”: EnforcedDisappearancesby Pakistan Security Forces in Balochistan”, 2011, http://www.hrw.org/sites/default/files/reports/pakistan0711WebInside.pdf (Erişim Tarihi: 17 Mart 2015).

Huntington, Samuel P. The Soldier and theState: The Theory and Politics of Civil-MilitaryRelations, Cambridge, BelknapPress of Harvard UniversityPress, 1985.

International CrisisGroup. "Pakistan: The WorseningConflict in Balochistan", Asia Report, No.119, 2006, http://www.crisisgroup.org/ /media/Files/asia/south-asia/pakistan/b69_pakistan_the_forgotten_ conflict_in_balochistan.pdf/ (Erişim Tarihi: 16 Mart 2015).

International CrisisGroup. "Pakistan: The ForgottenConflict in Balochistan", AsiaBriefing, No.69, 2007, http:// www.crisisgroup.org/ /media/Files/asia/south-asia/pakistan/b69_pakistan_the_forgotten_conflict_ in_balochistan.pdf/ (Erişim Tarihi: 16 Mart 2015).

Jones, OwenBenneth. Pakistan: Eye of theStorm, New Haven, Yale UniversityPress, 2002.

Khalil, Tahir. "Civil, MilitaryLeaders' Rift on BalochistanWidens", 12 Şubat 2012, http://www.thenews.com. pk/Todays-News-13-12403-Civil-military-leaders-rift-on-Balochistan-widens (Erişim Tarihi: 10 Nisan 2015).

Khattak, Inamullah. “RoadmaptoResolveBalochistanTangleUnveiled”, Dawn, 27 Ekim 2008, http://www.dawn. com/news/327299/roadmap-to-resolve-balochistan-tangle-unveiled (Erişim Tarihi: 2 Nisan 2015).

Lieven, Anatol. Pakistan: A Hard Country, London, AllenLane, 2011.

Lindemann, Stefan. "The EthnicPolitics of CoupAvoidance: EvidencefromZambia and Uganda”, AfricaSpectrum, Cilt 46, No.2, 2011, s.3-41.

Mustikhan, Ahmar.“Musharraf'sHiddenWar”, New Internationalist, No.396, http://newint.org/columns/currents/2006/12/01/pakistan/ (Erişim Tarihi: 16 Mart 2015).

“Over 1,100 People Missing in Balochistan, Says Malik”, Dawn, 28 Ağustos 2008, http://www.dawn.com/ news/318655/over-1100-people-missing-in-balochistan-says-malik (Erişim Tarihi: 17 Mart 2015). 
Pakistan Senatosu. "Report of theParliamentaryCommittee on Balochistan", http://www.senate.gov.pk/uploads/documents/1308267066_685.pdf, (Erişim Tarihi: 12 Mart 2015).

“Pakistan'sGasFieldsTargeted as BaluchRebelsAvengeRape", The Guardian, World News Connection, 21 Şubat 2005 (Erişim Tarihi: 8 Mart 2015).

Pande, Apama.ExplainingPakistan's Foreign Policy: EscapingIndia, New York, Routledge, 2011.

Rizvi, Hasan-Askari.Military, State and Society in Pakistan, New York, St. Martin'sPress, 2000.

Rudolph, Lloyd I. ve SusanneHoeberRudolph. "Generals and Politicians in India”, Pacific Affairs, Cilt 37, No.1, 1964, s.5-19.

Sechser, Todd S. “Are Soldiers LessWar-PronethanStatesmen?”, Journal of ConflictResolution, Cilt 48, No.4, 2004, s.746-774.

Shafqat, Saeed.Civil-MilitaryRelations in Pakistan: FromZulfikar Ali Bhutto toBenazir Bhutto, Colorado, WestviewPress, 1997.

Shah, Ali Syed.“BalochistanUnrest: 592 MutilatedBodiesFound in Last Three Years”, Dawn, 12 Eylül 2013, http://www.dawn.com/news/1042164 (Erişim Tarihi: 10 Nisan 2015).

Shahid, Saleem. "BalachMarriKilled: Violence in Quetta, Schools Closed",Dawn, 22 Kasim 2007, http://www. dawn.com/news/277009/balach-marri-killed-violence-in-quetta-schools-closed (Erişim Tarihi: 17 Mart 2015).

Sisson, Richard ve Leo E. Rose.War and Secession: Pakistan, India and theCreation of Bangladesh, Berkeley, University of California Press, 1990.

United StatesDepartment of State. “2010 Human Rights Report: Pakistan”, 2011, http://www.state.gov/documents/organization/160472.pdf (Erişim Tarihi: 6 Nisan 2015).

United StatesDepartment of State."Pakistan 2012 Human Rights Report”, 2013, http://www.state.gov/documents/organization/204621.pdf (Erişim Tarihi: 10 Nisan 2015).

Unrepresented Nations and PeoplesOrganization. "Balochistan: FormerSenatorCondemnsTactics of PakistaniArmy”, 2010, http://unpo.org/article/11346 (Erişim Tarihi: 10 Nisan 2015).

Walsh, Declan.'Pakistan'sSecretDirtyWar”, The Guardian, 29 Mart 2011, http://www.theguardian.com/ world/2011/mar/29/balochistan-pakistans-secret-dirty-war (Erişim Tarihi 10 Nisan 2015).

Weeks, Jessica L. "Strongmen and Straw Men: AuthoritarianRegimes and theInitiation of International Conflict”, AmericanPoliticalScienceReview, Cilt 106, No.2, 2012, s.326-347.

“WhoKilledBalochLeaders?”, Dawn, 25 Mayis 2009, http://www.dawn.com/news/965267/who-killed-thebaloch-leaders (Erişim Tarihi: 6 Nisan 2015).

Wirsing, Robert G. BalochNationalism and theGeopolitics of EnergyResources: The ChangingContext of Separatism in Pakistan, Carlisle, Strategic StudiesInstitute, U.S. ArmyWarCollege, 2008. 